\title{
WHOSE MONEY IS IT ANYHOW?: GOVERNANCE AND SOCIAL INVESTMENT IN COLLECTIVE INVESTMENT FUNDS
}

\author{
R. Kent Weaver*
}

CRR WP 2003-07

May 2003

\author{
Center for Retirement Research at Boston College \\ 550 Fulton Hall \\ 140 Commonwealth Ave. \\ Chestnut Hill, MA 02467 \\ Tel: 617-552-1762 Fax: 617-552-1750 \\ http://www.bc.edu/crr
}

*R. Kent Weaver is a Senior Fellow at the Brookings Institution. The research reported herein was performed pursuant to a grant from the U.S. Social Security Administration (SSA) funded as part of the Retirement Research Consortium. The opinions and conclusions are solely those of the author and should not be construed as representing the opinions or policies of SSA, or any agency of the Federal Government or of the Center for Retirement Research at Boston College.

(C) 2002, by R. Kent Weaver. All rights reserved. Short sections of text, not to exceed two paragraphs, may be quoted without explicit permission provided that full credit, including (C) notice, is given to the source. 


\title{
About the Center for Retirement Research
}

The Center for Retirement Research at Boston College, part of a consortium that includes a parallel center at the University of Michigan, was established in 1998 through a 5-year grant from the Social Security Administration. The goals of the Center are to promote research on retirement issues, to transmit new findings to the policy community and the public, to help train new scholars, and to broaden access to valuable data sources. Through these initiatives, the Center hopes to forge a strong link between the academic and policy communities around an issue of critical importance to the nation's future.

\author{
Center for Retirement Research at Boston College \\ 550 Fulton Hall \\ 140 Commonwealth Ave. \\ Chestnut Hill, MA 02467 \\ phone: 617-552-1762 fax: 617-552-1750 \\ e-mail: crr@bc.edu \\ http://www.bc.edu/crr
}

\section{Affiliated Institutions:}

Massachusetts Institute of Technology

Syracuse University

The Brookings Institution

Urban Institute 
Over the past two decades, an aging population and budgetary stress have led to substantial changes in public pension systems throughout the world. Many countries initially responded to pension funding crises with incremental reforms, including retrenchment of existing pension commitments (e.g., lowering replacement rates and increasing retirement ages in defined benefit systems) and by raising payroll taxes or increasing commitment of general tax revenues to pay pensions.

A number of countries have also engaged in a more fundamental restructuring of their pension systems, both to deal with current problems in their public pension systems and to prepare for the coming demographic shock of the Baby Boom retirement. The reform that has received the most attention is a shift in some countries toward a pension system (or one tier in a multi-tier pension system) of compulsory, universal advanced funded "defined contribution" individual accounts in which eventual retirement benefits are linked to an individual's contributions over his/her working life and the accrued earnings on those contributions.

A number of countries have also made changes in their defined benefit pensions, moving away from traditional Pay-As-You-Go financing practices toward building up collective investment "reserve" or "buffer" funds (Iglesias and Palacios, 2000; Palacios, 2000; Jacobs, 2002). Some of those countries, including Canada, New Zealand and Sweden, have also moved towards investing those surpluses in a broader array of instruments rather than the traditional low-return, low-risk lending to governments and

\footnotetext{
${ }^{1}$ The research reported herein was partially funded pursuant to a grant from the U.S. Social Security Administration (SSA) funded as part of the Retirement Research Consortium at Boston College. The opinions and conclusions are solely those of the author and should not be construed as representing the opinions or policy of SSA or any agency of the Federal Government.
} 
(in some countries) housing authorities. Collective investment of Social Security trust funds in a broader range of securities was also proposed in the United States by President Clinton, but it has been strongly opposed by President George W. Bush and Federal Reserve Board Chairman Alan Greenspan, and seems unlikely to move forward while a Republican administration is in office.

Finally, some countries have changed the governance of tax-privileged pension savings to provide increased incentives for private retirement savings, despite very mixed evidence about whether such incentives are effective in increasing overall savings rates.

These seemingly disparate responses to the pension funding crisis in fact raise a common set of issues about the public/private divide in governance of such funds. Should their purpose be solely to maximize returns for their (individual or collective) beneficiaries, or should they serve "public" ends as well? Should they, for example, stress domestic investment that may increase jobs within their home country, or should they spread investment risks across a range of global investments? Should they consider social and environmental criteria in investments - for example, by foregoing investments in companies that produce weapons or tobacco, or countries that have poor pollution or human rights records? And if they should pursue public objectives, what ends should they serve, and who should decide what those ends are? How should these investment funds be protected from the potential that groups within their societies will in fact use ostensibly "public" mandates to pursue their own political objectives or economic interests?

These questions have been posed in particular for collective investment funds in partially-funded defined benefit pension systems. Critics of proposals to increase use of, 
and broaden the investment range of, collective investment "buffer" funds argue that that their decisions will inevitably become politicized (See Tamagno, 2001); rather than seeking to maximize fund value, they will be used to bail out failing industries, squandering workers' contributions. Governments may also force them to loan to government at below market rates, lowering returns available for lower pension payouts. Rather than spreading risks across all investment opportunities, they will be forced to invest domestically, which may expose them to excessive country-specific risks of poor economic performance, especially in very small economies. And they are likely to become a battleground between forces on the left, who may favor requirements for social and environmental investment criteria and shareholder activism in corporate governance issues, while political conservatives posit conflicting priorities. Collectively, these "political risks" of sub-optimal returns are used by critics of collective "buffer" funds to argue for pre-funding of future pension liabilities through individual accounts rather than collective funds.

A recent World Bank study by Iglesias and Palacios (2000) suggests that publiclymanaged pension funds are likely to produce below-market returns on investment, and that these political risks are likely to be especially severe in countries with overall governance problems. But individual accounts have potential shortcomings of their own, such as potentially very high administrative costs, and uneven financial market and annuitization returns across cohorts, that raise concerns about them as well. And the costs of financing a transition to a fully-fund system of individual accounts are seen by politicians in most democratic countries as ranging between daunting and impossible. Broadening the range of investments and increasing the returns of collective buffer funds 
(especially where they are already in place), on the other hand, is seen by many

politicians as the political equivalent of a free lunch-a way to meet existing expectations about future pension commitments without resorting to benefit and eligibility cuts or contribution increases.

Iglesias and Palacios note (2000, p. 7), moreover, that public management of pension funds should be regarded as a continuum rather than as an "all or nothing" proposition. Countries vary in the investment criteria they use for investments, in the degree to which they are involved in the management of public funds, and in the degree to which management functions are contracted out to private managers. Palacios (2002) has identified a number of practices that can improve the returns on assets in collective pension reserve funds by reducing political risks. These practices include governance procedures that limit the role of politicians; an independent board with expertise in finance;, outsourcing of many functions; clear, written investment policies that 'make explicit the Board's position on shareholder activism, social investment and economically targeted investments" (p. 10) and focus on returns to plan members as their overriding objective; effective financial reporting with regular comparison against "objective benchmarks" (e.g. stock index performance); and regular reporting to the public on investment returns, costs, and compliance with governing regulations.

This paper examines how several OECD countries have addressed the "public/private divide" in collective investment "buffer" funds, drawing on the experience of Canada, New Zealand and Sweden, as well as the Swedish experience with a "default fund" (for those who do not make an active fund choice) in the individual account defined contribution tier of its public system. While most of these programs are 
quite new, they nevertheless provide some interesting and useful lessons about the potentials and pitfalls of such funds.

\section{CANADA AND QUEBEC}

Canada operates a multi-tier public pension system, including a quasi-universal (clawed back for upper income recipients) Old Age Security program, and an incometested tier made up of the Guaranteed Income Supplement and an Allowance for their spouses and common law partners aged 60 and above. Both of these tiers are financed out of general revenues. There is also a third, earnings-related tier financed through payroll taxes. But because this third tier is within provincial jurisdiction, provinces can opt out to operate their own program. One province, Quebec, has done so since the inception of the program in the 1960s. The result is an earnings-related Canada Pension Plan (CPP) operated outside Quebec and a parallel Quebec Pension Plan (QPP) that are integrated in almost all of their benefit and contribution provisions.

Both the CPP and QPP have had collective investment funds since their inception, but their investment practices have been very different. Until recently, CPP surpluses were loaned out to provincial governments at the federal government's borrowing rate, which was generally lower than their own. Thus unlike many other countries, it was provincial governments rather than the federal government that benefited from their ability to borrow at below-market rates. The Quebec Pension Plan has always invested in a broader range of financial instruments, including equities and real estate.

In the 1990s, a funding crisis in the CPP and QPP led to a broad consensus on the need to raise revenues and returns in order to address anticipated long-term funding 
shortfalls. Payroll tax rates were raised dramatically—-from a total of 5.6 percent (employers and employees each paying half) in 1996 to $9.9 \%$ by 2003. For the Canada Pension Plan, provinces were required to eventually pay higher rates on borrowings from the CPP. More importantly, current CPP surpluses generated by higher payroll taxes are being invested in a broader range of securities, including equities, with these investments managed by an independent board.

This change in investment practices moves the CPP closer to the practices of the Quebec Pension Plan, which has long invested in a diverse set of assets through the Caisse de dépôt et placement du Québec (CDP), a unique Quebec institution that invests not only QPP funds, but also on behalf of Quebec public sector employee pension funds, public insurance funds, agricultural marketing boards and other Quebec financial institutions. Other public sector pension funds, including the huge Ontario Municipal Employees Retirement System (OMERS) and Ontario Teachers' Pension Plan are also major players on Canadian equities and real estate markets.

Although the Caisse served as a model for the new Canada Pension Plan Investment Board (CPPIB) in some ways, the two organizations are very different in their mandate, size and relationship to their sponsoring governments. Indeed, the CDP and the CPPIB represent strikingly different models for a pension plan investment fund. Perhaps the most obvious difference between the two entities is the greater size and broader range of clients served by the Caisse. While the CPPIB invests only for the Canada Pension Plan, the Quebec Pension Plan is only the second largest depositor for the Caisse, behind Quebec's provincial employee pension fund. With a total of $\$ 133$ billion (Cdn.) in assets under management at the end of 2001, the Caisse has the largest portfolio of Canadian 
equities and the largest real estate portfolio in Canada. It is also the largest provider of private market and venture capital in Canada. The CPPIB, by contrast, managed only $\$ 17$ billion (Cdn.) in equity and real estate assets as of September 2002, with the federal Department of Finance holding another \$38.4 billion in fixed-income securities.

The Caisse and CPP Investment Board also differ greatly in their governmental links. The Caisse has, since its founding in 1966, been closely linked to the Quebec government. Indeed, it is the linchpin of what has been called "Quebec, Inc.," a close alliance of the Quebec government and Quebec francophone business leaders. (Arbour, 1993). These links are reflected in its governance procedures: all members of the Caisse's board of directors are appointed by the Quebec government, including the Chairman, who also serves as CEO. The head of the Régie des rentes du Québec, the agency that administers the Quebec Pension Plan, serves as vice chair of the board. Of the nine additional members of the board, two slots are reserved for heads of Quebec government agencies or officers of the Government, one from public employee unions, and one from the directors of cooperative associations. To protect the chairman of the Caisse from political interference, he or she is appointed for a term of ten years and removable only by a vote of the Quebec National Assembly, while other board members serve three-year terms. In practice, Caisse CEOs have generally had close ties to the provincial governing party (Authier, 1994; Dougherty, 2002). Indeed, the joint Chair/CEO system was installed in 1995 by the new Parti Québécois government, replacing a system of a separate board chair and president both responsible to the National Assembly that was put in place by the previous Liberal government. The change coincided with the ouster of a Caisse chair and president with close ties to the Quebec Liberal Party. 
In 2002, the Caisse's management proposed governance changes that would have given the Caisse's board a majority of independent directors, split the roles of chairman and CEO, and given the Caisse's Board rather than the Quebec government the lead role in appointing the Caisse's CEO. However, these recommendations were rejected by the Quebec government (Caisse de Depot, 2002; see also Gibbens, 2002). The CEO of the Caisse stepped down almost immediately, prompting speculation that the Parti Québécois provincial government, facing an uphill re-election battle in little more than a year, wanted to put in place a new chief executive for a new ten year term who would be sympathetic to its views even after it had lost office (DeCloet, 2002).

Governance procedures for the CPP Investment Board are very different. The legislation establishing the Board set up a complicated appointment procedure for CPPIB's Board of Directors that gives final responsibility to the Federal Minister of Finance and the federal Cabinet, but utilizes a federal-provincial nominating committee in which the federal government nominates the chair and each participating province nominates one member. . The CPP Investment Board Act requires that the composition of the board reflect "the desirability of having directors who are representative of the various regions of Canada and having on the board of directors a sufficient number of directors with proven financial ability or relevant work experience such that the Board will be able to effectively achieve its objects" (Revised Statutes of Canada, 1997, c. 40; see also Tamagno, 2001 and Sarney and Preneta, 2001/2002). Staggered terms of three years for the Board give it some additional protection from government interference. In contrast to the Caisse, current members of the federal and provincial legislatures and employees of both levels of government are barred from membership on the Board. 
Unlike Sweden and some other countries with collective investment funds, the CPPIB Board does not have reserved seats for "social partners" (business and labor). In the short history of the CPPIB, appointees to the Board have generally had financial sector experience rather than political or governmental experience, although one board member is a former Member of Parliament who had responsibility for federal-provincial pension policy consultations in the period leading up to the $1997 \mathrm{CPP}$ reform. The Board chooses CPPIB's President, who serves as CEO (government has no role in the selection). John McNaughton, the only person to hold the post so far, is the non-political, recently-retired head of a major Canadian investment firm.

Staff size and outsourcing philosophy are two additional points of contrast between the Caisse and CPPIB. The Caisse performs most of its analysis and portfolio management functions in-house, and had a staff at the end of 2001 of more than 500, not including its huge real estate arm. The staff of CPPIB, on the other hand, is small —under thirty people - and is expected to remain so. The CPP Board and senior management have decided that the organization should operate as a "virtual corporation" relying heavily on outside managers and investment partners to handle most portfolio management.

Both the Caisse and the CPPIB are subject to limits on the percentage of nonCanadian assets that they can hold. These limits mirror those for Registered Retirement Savings Plans, a rough equivalent to American 401(k) plans, which until recently were set at 20 percent of total assets. When the RRSP limit on foreign assets was raised to 25 percent in 2000 and 30 percent in 2001, the Caisse and CPPIB levels were raised as well. But the Caisse and the CPPIB differ strongly in their investment mandates and practices. 
From the outset, the Caisse has had a dual mandate: producing a strong return for investors and promoting the economic development of Quebec. Indeed, as one analyst put it, the Caisse was conceived in part as a mechanism to use "the collective savings of Quebec citizens...to...reduce the political influence of the anglophone financial establishment in Quebec.” (Brooks, 1987: 320) Unlike the CPP, the Quebec Pension Plan has through the Caisse invested in equities since its inception, sometimes quite aggressively. It has, for example, bought large stakes in companies such as the forest products company Domtar, which has large Quebec operations. In some cases, it has coordinated its purchases with a Quebec government economic development agency, the Société générale de financement du Québec (SGF). The Caisse’s governing statute explicitly restricts its holding more than 30 percent of the common shares of any enterprise except in situations such as start-ups, a need to continuity of operations during market turn-arounds, corporate reorganizations and lead-ups to a public issue. Normally investments over the 30 percent limit are limited to five years, but the Caisse's investment policy allows for exceptions. (Caisse de dépôt et placement du Québec, no date)

In recent years, the Caisse has been involved in several takeovers that have sparked widespread criticism, and produced major losses. In the late 1980s, it bankrolled at effort to keep the Quebec grocery firm Steinberg's in Quebec hands--a bid that eventually ended up with the collapse of Steinberg's and major losses by the Caisse (Arbour, 1993: pp. 46-55). In 2001, the Caisse teamed up with the Quebecor media group to block a merger between the Quebec-based Le Groupe Videotron Ltee. cable television company and the Ontario-based Rogers Communications cable firm. The deal 
kept Videotron in Quebec hands but left Quebecor with an unsustainable debt load and the Caisse with a 45 percent stake in Quebecor's media subsidiary—and a write-off of almost a billion dollars. However, the Caisse has not had to endure substantial controversy over environmental or other social policy investment criteria.

Overall, the Caisse earned a 9.34 average return in the ten year period ending in 2001, despite a -4.99 return in the final year of this period. This was far better than the CPP, which had invested in exclusively in bonds for most of that period. But critics note that its return was well below the best private plans- the Ontario Teachers' Pension Plan returned 11.6 annually over the same period — and attribute the difference to politically motivated investments and an over-concentration of investments in Quebec.

In setting up the Canada Pension Plan Investment Board, the Caisse's aggressive investment practices and economic development mandate served as both a positive and negative example. The CPPIB is supposed to achieve a "maximum rate of return, without undue risk of loss." But the CPPIB's mandate does not include additional industrial policy or social policy objectives. Many features of the Canada Pension Plan Investment Board governance structures were set precisely to prevent movement away from an exclusive focus on maximizing returns with reasonable risk.

To diversify the overall portfolio of the Canada Pension Plan—initially composed entirely of provincial bonds - the CPPIB from the outset initially decided that it would invest all of the funds transferred to it in equities. The CPPIB does have important limitations on its investment allocations, however. As noted above, the CPPIB is subject to a 30 percent limit on foreign assets. CPPIB is also prohibited from holding, directly or indirectly, more than thirty percent of the voting shares of any company. Other 
restrictions on the Board are intended to limit its exposure both to particular types of investments (e.g., real estate and natural resources) and in particular firms or projects. Section 11 of the Board's investment regulations limit it to having no more than ten percent of its assets in the securities of any group of affiliated persons or organizations. In addition, CPIB cannot have more than five percent of its assets in any single "real property or Canadian resource property," hold more than fifteen percent of its assets in all Canadian resource properties, or more than a total of 25 percent of its assets in all real property and Canadian resource properties. The CPPIB's authorizing legislation also requires the consent of two-thirds of provinces participating in the CPP, with a population of at least two-thirds of the total population of participating provinces, to consent to any change in the Board's investment regulations. Thus is unlikely that any plausible combination of future governments would be able to shift CPPIB's focus toward industrial or social policy objectives.

The CPPIB has been given both more tasks and more freedom over its relatively short life-span. Initially, the CPPIB was required to manage all of its Canadian equities portfolio passively by "substantially replicating" the Toronto Stock Exchange (TSE) 300. The requirement for passive investing was later reduced to half of the Canadian equities portfolio and eliminated entirely in the fall of 2001. In the summer of 2002, the government announced its intention to hand over management of CPP's bond portfolio to the Investment Board as well.

Saying that domestic investment standards have been relatively depoliticized does not mean that they have been problem-free, however. Implementing these standards in the relatively small Canadian equities market has created problems. The original 
mandate of the CPP Investment Board to invest 80 percent of its funds passively in Canadian equities quickly came into conflict with its mandate to limit exposure to one firm: at the height of the telecommunications boom at the turn of the new millennium, Northern Telecom was valued at more than one-third of the total value of the TSE 300 index. Late in 2000, the CPPIB utilized its newly-granted authority to invest more actively to begin using a "TSE 299" to limit its financial exposure to Northern Telecom. This allowed it to reduce its exposure to Northern Telecom to about 4 percent of its equity portfolio at the end of the 2000-2001 fiscal year - and reduce its equity losses by about $\$ 535$ million in that year and $\$ 121$ million in the following year over what would have otherwise occurred if it had remained overconcentrated in Northern Telecom. CPPIB reverted to index investing in the third quarter of its 2001-2002 fiscal year when Nortel no longer dominated the index. (CPPIB, 2001, p. 5; CPPIB 2002a, p. 14) More generally, the CPPIB has expressed concern that relatively large (by Canadian standards) inflows of $\$ 6$ to $\$ 8$ billion per annum expected from CPP payroll taxes over the next few years could contribute to a bidding up of Canadian equity prices as well as inadequate diversification of assets--betting too much on the performance of the Canadian economy - under current investment rules (CPPIB, 2002a, p. 7).

At the end of September 2002, just under 30 percent of all CPP assets were invested in public and private equity — primarily the former. The Canada Pension Plan Investment Board has recently begun to implement a policy to actively rather than passively invest up to half of its Canadian equity assets, while keeping portfolio management costs low. Its most recent Investment Statement plans a continued emphasis on public equities, with between 75 and 100 percent of total assets to be held in these 
assets, with between $45 \%$ and $75 \%$ of the total portfolio in Canadian equities, 5 and $25 \%$ in U.S. equities, and 5\% and 25 in public equities from other countries. (CPPIB, 2002c, p. 8)

The CPPIB has also begun working in partnership with merchant banks and other pension funds to take advantage of venture capital opportunities while spreading risks and minimizing its exposure to political flak by taking minority stakes in funds managed by other parties. By the end of the 2002 fiscal year, 3.2 percent of CPPIB's assets were invested in these vehicles, and the Board has declared its intention to invest up to ten percent of total CPP assets in private equity with another five percent in real estate, natural resource development projects and other private markets assets. (CPPIB, 2002a, p. 9); CPPIB, 2002c, p. 8) While there are no legal or regulatory requirements that CPPIB's private market investments be skewed toward Canada, the firm's vice-president for private market investments has stated that CPPIB is "making a special effort to find the best opportunities at home before venturing too far abroad." ${ }^{2}$

The CPPIB has also taken a very cautious stand on social and environmental investment criteria. In March 2002, the Board adopted a Social Investing Policy statement that argued that (1) its "statutory mandate and fiduciary duty are based exclusively on investment considerations," (2) responsible corporate behavior in fact usually contributes positively to investment returns in the long run, and (3) the religious, ethical, social and other views of Canadians are so diverse that they could not possibly be reflected in the Board's investment decisions. Therefore, although the Board would generally "support corporate policies and practices that would result in the disclosure of 
information that could assist investors in assessing whether corporate behavior was contributing to or detracting from long-term investment returns," it would not use notinvestment criteria to screen in or out any investments. Instead, it would consider for investments "the securities of any issuer engaged in a business that is lawful in Canada" and "the securities of issuers in any country with which Canada maintains normal financial trade and investment relations." (CPPIB, 2002d).

In the absence of screening in or out specific investments, CPPIB's other major mechanism for expressing social or environmental concerns relates to voting its shares. Once again, CPPIB has taken a largely passive approach, delegating its voting rights to external fund managers in most situations.

The CPPIB's investment performance has reflected the roller-coaster ride of equity prices in recent years. In the Board's first few years of operation. CPPIB enjoyed very strong returns, followed by a disastrous 2000-2001 fiscal year, in which the fund lost $\$ 845$ million on investments (-9.4 percent return), and a modest gain in 2001-2002 (+3.4 percent return). Overall, the CPPIB has lost money on its investments since its inception, because the inflow of funds as CPP payroll taxes rose meant that many more funds were at risk in the last few years of operations than in earlier years. Although CPPIB has beaten its domestic and foreign equity portfolio benchmarks in recent years, poor equity markets have caused it to fall short in both 2000 and 2001 of the actuarial target assumptions used by the Canadian government in projecting the long-term viability of the Canada Pension Plan. (CPPIB, 2002a, p. 15)

\footnotetext{
${ }^{2}$ Mark Weisdorf, CPPIB vice president for private market investments, quoted in CPPIB,
} 


\section{SWEDEN}

Sweden has had collective investment funds as part of its contributory earnings related pension system since that system was created in the late 1950s. The "buffer funds" were intended in part to compensate for an anticipated decline in personal savings as Swedes came to expect a larger state pension. The buffer funds were relatively small, however, and most of the funds were loaned out to government and housing authorities (see Pontusson, 1994).

Sweden expanded the role played by the buffer funds as part of a comprehensive pension reform debated through most of the 1990s and enacted in stages from 1994 to 1998. The pension reform created a new "premium pension tier" of individual accounts, and converted the defined-benefit flat-rate and supplemental earnings-related pensions into a dramatically restructured "Notional Defined Contribution" (NDC) earnings-related pension tier. The higher the return that the buffer funds offer, the more likely it is that the new NDC "Income Pension" will be able to meet its planned funding commitments without triggering benefit cuts through a new "automatic balancing mechanism." (see Settergen, 2001 and Palmer 2002)

The current fund system was created by a complicated shuffling of assets held by the old buffer funds and the creation of four new bodies, collectively known as the First to Fourth Swedish National Pension Funds, or First to Fourth AP Funds for short. Another existing fund, the Sixth AP Fund, which was set up primarily to provide funding for unlisted companies, is much smaller. It was left largely untouched by the reforms and will not receive new funds on an annual basis like the others. There is no Fifth AP fund

2002b. 
under the current system. The four main buffer funds received initial funding of more than 150 billion kronor, or 15 billion U.S. dollars. An additional, $7^{\text {th }}$ AP Fund was created to serve as the repository for the funds of those who do not make an active choice under the individual accounts tier of the pension system.

The First to Fourth AP funds were given roughly equivalent portfolios at the outset that reflected the old ATP funds' heavy reliance on government securities. They were also given a complicated set of mandates and restrictions on investment practices. Overall they were told that:

The AP Funds should manage their assets to achieve the greatest possible benefit in safeguarding the income-related pension system. Their allocation of assets should be based on an analysis of the pension system's liabilities. The goal should be to maximize long-term return on capital in relation to investment risk. The funds should carry out their asset management with appropriate diversification of risk. The overall risk level in their asset management should be low. Industrial policy or other economic concerns must not be involved. The funds should take ethical and environmental considerations into account without relinquishing the overall goal of a high return on capital. (Sweden, 2000)

While this mandate is relatively clear in some respects - $a$ ban on industrial policy considerations in particular-- it is contradictory on others. The fund was supposed to take a low risk strategy, for example, but it was also supposed to keep in mind its pension liabilities, and a strategy that focused primarily on risk minimization would probably not be able to meet those liabilities. The wording on ethical and environmental investment 
criteria suggests that maximizing return "should not be relinquished" as a goal but that it should be tempered to some undefined extent. The legislation also contained a complex array of investment restrictions, including requirements that:

- at least thirty percent of each fund's assets be in low-risk interest bearing securities,

- no more than ten percent of any funds assets "may be exposed to a single issuer or group of issuers,"

- no individual fund hold more than ten percent of the voting shares of any listed company,

- at least ten percent of each funds money be managed externally by January 2002 ,

- no more than five percent of assets of any fund can held in unlisted securities, and that any such investments should be made indirectly, and

- no fund may hold equity holdings in Swedish companies greater than two percent of the capitalization of the Stockholm stock exchange.

There were no direct requirements that a minimum share of investments be in Swedish assets--which could have been highly problematic given Sweden's EU membership--but no more than 40 percent of assets were supposed to be exposed to currency risk. This would allow the funds to use currency hedges to invest a greater share of their funds outside Sweden.

The governance arrangements for the funds added another layer of complexity to the system. Government is not allowed to issue directives to the firms, but employer and employee interests are represented directly on Fund's boards, nominating two representatives apiece to each Fund's nine member board. Moreover, board members 
serve only one-year terms, so that government can presumably replace an uncooperative board in relatively short order if it chooses to do so.

The new buffer fund system is still very new — funds were transferred only at the beginning of 2001, with each of AP Funds 1-4 receiving identical portfolios of assets of about $\$ 134$ billion dollars (roughly \$US14 billion), split between 69 percent in bonds and 31 percent equities. But some patterns are already emerging, and are evident in Table 1. First, each of AP Funds 1-4 has moved rapidly to change its asset mix to invest much more heavily in equities. By the end of 2001, all four funds had a majority of their funds in equities, ranging from 51.5 percent for AP3 to 63.3 percent for AP4. The four funds also differ in the degree to which they hold Swedish equities, with a range of between 12 and 24 percent of total assets.

A second area of difference includes their attitudes toward internal versus external portfolio management and internal versus external management. The First AP Fund has set a goal of managing the bulk of its portfolio both actively and internally, for example, while the Second AP Fund has adopted a near-term strategy of relying almost entirely on external management. These differences reflect changes in the two organizations' histories-AP1 inherited much of the staff of the old buffer funds in Stockholm, while AP2 was started from scratch in a new city, Göteborg--and are in turn reflected in the two funds' employment at the end of 2001, with AP1 having more than twice as many employees (65) as AP 2 (28).

It is too early to say whether competition between the AP funds has spurred improved performance, but this competition has to some extent been institutionalized. The First AP Fund, for example, has instituted an employee bonus system that is based in part on 
beating the performance of Funds AP2 to AP4 and in part on beating benchmark indexes established for each part of the Fund's portfolio. (First National Swedish Pension Fund, 2001, p. 27)

The different funds are also taking somewhat different stances on social, environmental and corporate governance concerns. The 2nd AP fund, for example, has been active in lobbying companies on environmental and business practices. It has disposed of stakes in two companies that did not provide adequate responses to their inquiries. The 3rd AP Fund, on the other hand, has focused on pressing Swedish companies to limit management bonuses, and has thus far paid limited attention to environmental issues.

Nor is there a complete consensus yet on the relatively non-restrictive investment practices carried out by managers of the state AP pension funds acting both as buffer funds for the income pension and a default for the premium pension. Leaders within the Social Democratic party have criticized the funds' practices as undermining Swedish industry in their single-minded pursuit of high short-term returns. Even Prime Minister Göran Persson has lamented current investment rules, arguing that a pensioner depends not only on "the yield in state pension funds, but also that Sweden has a functioning industry that pays taxes in Sweden. That is the crucial security for me as a pensioner." (Svensson, 2001). The head of the Seventh AP-Fund, which administers the default fund for non-choosers, has vigorously defended current investment practices as necessary to protect the value of future pensions (Feldt and Norman, 2001).

The Swedish experience with the premium pension also suggests that moving to an individual account system will not necessarily eliminate debate over domestic, ethical 
and environmental investment practices. Indeed, the $7^{\text {th }}$ AP Fund, the default fund for those who do not make an active choice in the individual account tier, has taken an even more aggressive stand on these issues than the other state pension funds. It decided to disinvest in companies that had been found guilty by impartial tribunals of violating international conventions to which Sweden had adhered, including conventions on human rights, child labor, various ILO conventions, international environmental conventions, and conventions against bribery and corruption. On the basis of these criteria, AP7 decided in 2001 to sell its shares in 27 companies, including such well-known multinational companies as Coca-Cola, General Motors, ITT, Nestlé, Sears, Texaco and WalMart, as well as one Swedish company, Esselte. Investment in those companies was to be barred for five years, although the Fund's board could restore them earlier if there was evidence that they had come into compliance with the relevant conventions. (Seventh Swedish National Pension Fund, no date, p. 2; Svenska Dagbladet, 2002) But the fund continued to invest in companies with interests in tobacco, gambling, alcohol and weapons production - indeed its general manager argued that since the Swedish state had interests in those same sectors, following such a rule consistently would mean that it would have to get rid of Swedish government bonds.

Reflecting the poor performance of equities generally (and Swedish equities in particular) in 2001, all of the Swedish buffer funds lost money in that year, reporting returns near those of their benchmark indexes (Table 1).Overall, it remains to be seen just how meaningful and useful competitition between the funds will be. The head of one AP Fund gave a mixed evaluation in an interview, noting that:

..I do feel the competition: no one wants at the end of the game to be last in performance when it comes to the highest costs or whatever. There are 
drawbacks and there are positives [to this]. The positives are that you are much more on your toes to perform better. The risk is that we don't differentiate ourselves enough., that we tend to look at one other and copy each other. Of course that's part of competition: you look at each other and copy the best ideas from competitors... But when it comes to pension fund management maybe it's a good idea if we tried to seek different solutions. The idea of having four separate funds was not only to have competition but to have separate solutions, and if you look at us, the separateness might be small. (Interview, May 2002)

\section{NEW ZEALAND}

New Zealand created a Superannuation Fund in 2001 to ease the future financing burden of its general-revenue financed, and flat-rate, superannuation program. This debate over whether buffer funds should be created, and if so, under what terms, is part of a bitter debate over what is one of the world's most highly politicized pension systems. In 1997, a coalition National/New Zealand First government proposed moving to an individual account pension system, which was rejected by more than 90 percent of voters who participated in a mail referendum. After coming to power in 1999, a minority Labour/Alliance coalition government proposed that a buffer fund be created as part of a “tax smoothing” effort to partially pre-fund the Baby Boomers' retirement.

In the absence of a dedicated funding source such as a payroll tax, there was substantial conflict over how a collective investment should be financed and how much money should be put into it. Adoption of a collective investment fund was also complicated by the fact that the governing coalition lacked a majority in the Parliament, and would have to win the support of at least one additional party (with the Greens or New Zealand First as the most likely candidates) to win approval for the legislation. A 
dedicated fund was opposed by the junior coalition partner, the left-wing Alliance, which feared that it would limit government's capacity to manage the economy. If a fund was to be created, they preferred that it be drawn from budget surpluses rather than a share of tax take, to make sure that it did not eat into social spending during lean times. The Greens also preferred to finance the fund out of overall surpluses rather than the income tax, because they want to leave political room for substituting eco-taxes for personal income taxes. But Winston Peters of New Zealand First argued that simply applying (highly uncertain) budget surpluses rather than a stable, dedicated revenue source to a superannuation fund was unacceptable.

Labour and its coalition partner Alliance also disagreed on whether any investment fund should be tilted toward investment in New Zealand: the Alliance (along with the Greens and the populist New Zealand First Party) were in favor, while Labour (and the conservative parties) were opposed. Many experts-including the Treasury-warned that investing predominantly in New Zealand's tiny and slow-growing economy was also a very high risk strategy for a retirement savings fund (MacAlister, 2000; Brockett, 2000; New Zealand Treasury 2000a). The Greens, on the other hand, were concerned that a fund oriented toward maximizing returns would ignore environmental considerations in its investment decisions--a position rejected by the other parties.

The coalition finally pushed legislation through Parliament in October 2001 with the support of New Zealand First after efforts to win a broad multi-party consensus failed. Responding to the concerns of the Alliance that the government retain spending flexibility to respond to future economic downturns, government contributions to the Fund are not set as a fixed share of tax revenues. Instead, after a phase-in period, 
government contributions are to be set as a percentage of GDP, such that contributing that level of GDP over the next forty years would be sufficient to fund anticipated Super expenditures over that period. (Treasury planners had initially planned on a sixty year funding time horizon, which would have required a higher contribution rate. See New Zealand Treasury, 2000b, chapter 12) When fully phased in (in 2004-2005), these contributions will initially total 5.54 percent of GDP, with 3.8 percent paid out immediately in benefits and the remaining 1.75 percent being invested. Total contribution rates are expected to rise over time as more "high cost" years were included in the 40 year planning horizon. The share of contributions being invested will begin to decline around 2010, as more funds were required to pay current benefits for retiring baby boomers. Fund assets are projected to peak between 2023 and 2029, then gradually decline to around zero near the end of the century. At its peak, the fund is supposed to pay for about ten percent of the costs of Superannuation benefits.

Governments can choose to contribute less than the GDP percentage required for level 40 year funding in any given year, although not less than the amount required to meet the net cost of Superannuation in the coming year. (Nor can they make net withdrawals from the fund before 2020, although a future parliamentary majority could change that restriction or any other aspect of the legislation). But if a government does choose to underfund for future obligations in a particular year, the legislation requires them to publish in the government's annual Fiscal Strategy Report the amount of the undercontribution, the reasons for it, and their intentions and strategy for making up underfunding in the future. In other words, transparency and fear of political retribution for poor stewardship of pensions are the main barriers against potential underfunding. 
The legislation also makes detailed provisions for the management and operation of the fund that are intended to limit interference. An elaborate nomination process for the fund's governing board (grandly labeled the "Guardians of New Zealand Superannuation") is imbedded in the law. The process is a curious mixture of group inclusiveness and provisions intended to shield the board--and the investment managers it hires--from political interference. The law requires the Finance Minister to call for board nominations from organizations who are likely to be interested in the Fund (notably those representing the elderly, employees, and savings institutions). A nominating committee, also appointed by the Prime Minister, will consider all nominations (including those from the groups). Final appointments to the board are to be made by Cabinet on recommendation of the Finance Minister, but the Minister is only allowed to appoint persons who (1) "in the Minister's opinion, ha[ve] substantial experience, training, and expertise in the management of financial investments," and (2) have been approved by the nominating committee. The legislation also requires that the Minister consult with other political parties before forwarding a nomination from the nominating committee for final approval. Appointment of the chief executive officer for the fund is the responsibility of the "Guardians" rather than government. And the board is given complete discretion in contracting out management of the fund or parts of it to one or more entities.

With regard to the operation of the fund, the main provisions are that it be managed on a "prudent commercial basis" following "best-practice portfolio management" while "maximizing return without undue risk to the Fund as a whole." Although the legislation does allow the New Zealand Finance Minister, after consultation 
with the Guardians of the fund, to give the Guardians directions with respect to "the Fund's performance, including the Government's expectations as to risk and return," it also states that "the minister must not give a direction that is inconsistent with the Guardians' duty to invest the Fund on a prudent, commercial basis." Moreover, those directions must be presented publicly to New Zealand's Parliament, and the Guardians are only required to "have regard to any direction given by the Minister" and state publicly how they are planning to respond, rather than being required to follow the Minister's directions.

The Guardians are not precluded from pursuing an active rather than passive fund management strategy, but the Fund is barred from having a controlling interest in any company. A very modest bow to the concerns of the Greens that the Fund undertake ethical investment practices was included by requiring that the Fund investments “avoid....prejudice to New Zealand's reputation as a responsible member of the world community." These provisions were, New Zealand's Finance Minister stated, intended to bar fund investments in "government securities of particularly obnoxious Governments that were dictatorships, or particularly obnoxious forms of companies engaged in strange criminal behavior," but not to require "invest[ment] only in companies that fulfilled some very strict criteria." ${ }^{3}$ Moreover, the legislation avoided both more specific directives or mechanisms that would give that directive more teeth. Nor were the Fund's investments to be limited to or skewed toward New Zealand.

\footnotetext{
${ }^{3}$ The provisions are in New Zealand Superannuation Act 2001, Public Act 2001, No. 84, section 58. The quotations are from Finance Minister Michael Cullen's answers to Green Party co-leader Rod Donald in Hansard, October 11, 2000, Question 1. On government resistance to more specific directives, see the exchange between Finance Minister Cullen and Green Party co-leader Rod Donald in Hansard, November 29, 2000, Question 3 ,and Small (2000).
} 
Up to 70 percent of the fund is expected to be invested abroad to spread the risks of poor economic performance in the New Zealand economy (Venter 2001). Critics of the government's proposal questioned the wisdom of taking huge quantities of New Zealand capital abroad and pointed to falling global equities markets and foreign exchange losses suffered by the government employees' pension fund as evidence that the fund was too risky (Howie, 2001).

Even after its adoption, the new Superannuation Fund plan could be dismantled or heavily modified by a simple majority in a future Parliament. That does not seem likely in the short term: in the July 2002 general election, superannuation was not a prominent issue, nor was it a major concern for the electorate. Labour increased its number of seats slightly, while its Alliance coalition partner split and virtually collapsed. Labour and its coalition partner the Progressive Coalition (a break-off of the former Alliance) are now seven seats short of a majority rather than just the two seats short before the election. But two other parties generally supportive of the Super Fund, New Zealand First (which would prefer an individual accounts system) and United Future New Zealand, together gained 16 seats, while National lost 12 seats (See Milne, 2002).

In the absence of a strong commitment from National as well as Labour, however, there is no guarantee that the New Zealand Superannuation Fund will remain in place for the long term. And even if it does, the lack of a guaranteed payroll tax funding mechanism increases the likelihood that a future government may underfinance the system. 


\section{CONCLUSIONS}

This very brief and selective review of the experiences of three OECD countries shows that collective investment funds are perceived by a variety of governments to be a viable option for dealing with the funding crisis associated with the retirement of the Baby Boom--even a country like New Zealand that does not have a dedicated funding source for pensions. But these funds pose a number of issues revolving around the "publicness" of the funds, notably how much influence governments should have in their governance, and whether "private" calculations of risk and return should be the only factors in their decisionmaking.

As shown in Table 2, there clearly is substantial diversity in the choices that countries make in structuring those funds. Differences are evident even within a single country, Canada, between the Canada and Quebec Pension Plans, and in Sweden, between the main "buffer" funds, AP1-AP4, the regional investment fund, AP6, and the default fund for the individual account system, AP7. All of the cases here except the Caisse show a clear focus on the "private" objective of increasing returns for the benefit of future pension beneficiaries, however, and the mechanisms they have evolved demonstrate a number of ways to advance that objective, such as clear statutory mandates to focus on economic risks and returns, insulated boards and nomination procedures for those boards, weak or non-existent domestic and social investment criteria, heavy use of external managers, and participation as a minority partner with private investment funds in private market investments.

The politics of investing collective buffer funds tends to reflect the broader politics of their countries in both style and substance. Sweden, for example, combines 
some deep ideological divisions with a consensus-building policy process that usually produces fairly broad agreement on how to proceed. Governance of the new buffer funds reflects long-standing Swedish practices of consultation with business and labor "social partners." Substantive debates on collective fund investment policies have focused on a variety of issues, including domestic investment, corporate ethics, and environmental and labor issues. How these different concerns will play out in practice remains to be seen. The development of the practices of the Swedish funds to deal with social and environmental investment criteria bear particular watching. New Zealand has difficulties in reaching broad agreements across partisan lines and in keeping important issues out of partisan politics. But its investment mandates thus far are weaker than those in Sweden. Canada, too, has taken a more hands-off approach to its buffer funds. On the other hand, Quebec, with a strong element of economic nationalism among its political elite, has been by far the most aggressive in using collective investment funds to promote regional economic development.

The evidence listed here also suggests that policy inheritances are important factors in explaining those differences. In particular, rules that are put in place in one part of a country's overall pension regime may simply be adapted for another part—e.g., in the adoption of foreign investment rules for the Quebec and Canada Pension Plans that originated with Registered Retirement Savings Plans. There also appears to be a strong element of both within country and cross-national learning, however, as most countries in recent years have moved away from an interventionist course toward a more "private" set of objectives and governance procedures when they set up new collective investment funds (New Zealand) or revised established ones (Canada and Sweden). But the Quebec 
Pension Plan's Caisse de dépôt — a product of the 1960s, when dirigisme and industrial policy were much more in vogue - has remained close to its original model of governance and investment practices.

Another lesson from these international experiences is that debates over investment criteria are likely to be a recurring issue rather than one that is resolved definitively when the initial legislation establishing buffer funds is enacted. The stakes are too large for such issues to be completely depoliticized. Even a strong set of insulation mechanisms could be challenged. Early evidence also suggests, however, that these funds can operate with a high degree of autonomy within their legislative mandates and match or exceed the returns of benchmark indexes, with very low administrative costs--at least in countries where the overall public governance structure is relatively sound.

The cases also suggest, even in the first few years of experience, some of the potential risks associated with domestic investment requirements, especially in countries with relatively small capital markets and few very large firms. Both the CPPIB and the Swedish buffer funds found themselves heavily exposed to a single firm--Northern Telecom in Canada, Ericsson in Sweden--as the telecomm boom peaked. Only deviation from passive index investment policies could limit this risk.

Finally, the Swedish experience also suggests that creation of multiple funds may be a useful way to sharpen the attention of fund managers on their fund's financial performance rather than other objectives. This approach is not without costs or problems of its own, however. First, creating multiple funds increases the costs of management. This is likely to be a particular issue in small countries like New Zealand. Second, a 
focus on the annual or even quarterly bottom line - or at least avoiding being at the bottom of a country's "league tables" for fund returns could lead fund managers to take excessive risks and/or focus on short-term returns rather than on building assets for the long term. An equally strong risk, however, given the small number of funds and incentives not to be the worst performer, is that multiple buffer funds might lead to more to imitation than to differentiation and innovation. 


\section{BIBLIOGRAPHY}

Arbour, Pierre, (1993) Quebec Inc and the Temptation of State Capitalism, Robert Davies Publishing.

Authier, Phillip (1994), "Parizeau Makes Changes at Caisse," Montreal Gazette, November 3, p. D1.

Brockett, Matthew (2000) "Invest Offshore Treasury Says," The Press (Christchurch), November 22, p. 6.

Brooks, Stephen, 1987) “The State As Financier: A Comparison of the Caisse de dépôt et placement du Québec and Alberta Heritage Savings Fund," Canadian Public Policy, vol 13, n. 3, pp. 318-329.

Caisse de dépôt et placement du Québec, (no date) « Policy applicable to Private Investments sector investments, with respect to the holding of more than $30 \%$ of a company's common shares."Available at http://www.cdp.ca/pdf/30pourcenta.pdf.Caisse de dépôt et placement du Québec, (2002) Modernizing to Ensure a Stronger Future: Recommendations Respecting the Governance of the Caisse de dépôt et placement du Québec, Quebec: The Caisse.

Canada Pension Plan Investment Board, (2001), 2001 Annual Report. Canada Pension Plan Investment Board, (2002a), 2002 Annual Report.

Canada Pension Plan Investment Board, (2002b), “CPP Investment Board Commits HalfBillion Dollars to Canadian Venture Capital," news release, June 19.

Canada Pension Plan Investment Board, (2002c) Investment Statement, September 11.Canada Pension Plan Investment Board, (2002d) Canada Pension Plan 
Investment Board, Social Investing Policy, March 6.DeCloet, Derek "Caisse Boss Falls On the Big Bets," National Post, May 18, 2002, p. FP1.

Dougherty, Kevin, (2002) “Rousseau’s Sovereignty Stance Key,” Montreal Gazette, May 30, p. C1.

Feldt, Kjell-Olof and Peter Norman, (2001) “Försämra inte pensionerna, Persson [Don’t endanger pensions, Persson], Dagens Nyheter, October 16.

First National Swedish Pension Fund,(2001) Annual Report, 2001.

Gibbens, Robert, (2002) “Landry Sparks Alarm Over Caisse,” National Post, May 23, p. FP1.

Howie, Craig (2001) "Super Fund Gets Burnt in Currency Dealings, The Dominion (Wellington), June 13, p. 1.

Iglesias, Augusto, and Robert J. Palacios. (2000), Managing Public Pension Reserves Part I: Evidence from the International Experience. Washington, D.C. January. Jacobs, Alan M. (2002) “Making Tradeoffs Over Time: Retrenchment, Investment and the Reform of Pension Systems." Paper presented at the 2002 annual meeting of the American Political Science Association, August 29-September 1.

Macalister, Philip (2000) “Super Myths Debunked,” New Zealand Herald, August 5. Milne, Jonathan, (2002) "Coalition Talks to Focus on Superannuation Funds," Southland Times, July 31, p. 2.

New Zealand Treasury, (2000a), Macroeconomic Effects of the Proposal for Pre-Funding New Zealand Superannuation, Treasury Report T2000/1939, September 18.

New Zealand Treasury, (2000b), Pre-Funding New Zealand Superannuation: Working Document, June 15. 
Palmer, Edwatrd (2002) "Swedish Pension Reform: How Did It Evolve, And What Does It Mean for the Future?," pp. 171-205 in Martin Feldstein and Horst Siebert, eds., Social Security Pension Reform in Europe, Chicago and London: University of Chicago Press.

Pontusson, Jonas (1994) The Limits of Social Democracy: Investment Politics in Sweden, Ithaca: Cornell University Press.

Sarney, Mark, and Amy N. Preneta (2001/2002) “The Canada Pension Plan's Experience with Investing Its Portfolio in Equities," Social Security Bulletin, vol 64, no. 2 , pp. 46-56.

Settergren, Ole (2001) "The Automatic Balancing Mechanism of the Swedish Pension System: A Non-Technical Introduction,” Stockholm, National Social Insurance Board, August 21.

Seventh Swedish National Pension Fund, (no date) Sjunde AP-fonden. Ar 2001[Seventh AP Fund, Year 2001].

Small, Vernon (2000), “Cullen Camp Tips Hands-Off Style on Pension Funds,” New Zealand Herald, October 23.

Svenska Dagbladet, (2002) “Coca-Cola och Nestlé åkte ut när AP-fond följde etikregler [Coca-Cola and Nestlé went out when AP fund followed ethics rules]," Svenska Dagbladet, February 22.

Svensson, Karin (2001), “Göran Persson vill ha blå-gula AP-fonder” [Göran Persson Wants to Have Blue and Yellow State Pension Funds], Dagens Industri, September 19. 
Sweden (2000) Government Bill 1999/2000:46 “The AP Fund in the Reformed Pension System," January 13.

Tamagno, Edward (2001). Investing Social Security Funds: Principles and Considerations, Ottawa, Caledon Institute of Public Policy, February.

Venter, Nick (2001) “Cullen's Super: The Risk and the Opportunity,” The Dominion (Wellington), June 9, p. 2. 
TABLE 1. CHARACTERISTICS OF SWEDISH BUFFER FUNDS

First Second Third Fourth Sixth

Asset Allocation as of 12/31/01

\begin{tabular}{|c|c|c|c|c|c|}
\hline Equities & 59 & 58 & 51.5 & 63.3 & N.A. \\
\hline Swedish equities & 12 & 21 & 17.9 & 24.3 & N.A. \\
\hline Global equities & 47 & 38 & 33.6 & 39 & N.A. \\
\hline Fixed income & 37 & 37 & 45.6 & 33.9 & N.A. \\
\hline Swedish fixed income & 12 & N.A. & 17.5 & N.A. & N.A. \\
\hline Global fixed income & 17 & N.A. & 20.9 & N.A. & N.A. \\
\hline Index-linked bonds & 8 & N.A. & 9.2 & 0 & N.A. \\
\hline Real estate & 3 & 3 & 2.9 & 2.9 & N.A. \\
\hline Cash & 1 & 1 & 0 & & N.A. \\
\hline $\begin{array}{l}\text { Return on total assets, } \\
2001\end{array}$ & -5.6 & -3.7 & -4.4 & -5 & -8 \\
\hline Benchmark index return & & -5.4 & -4.6 & -4.5 & -14.2 \\
\hline $\begin{array}{l}\text { Employment, average for } \\
2001\end{array}$ & 64 & N.A. & N.A. & 39 & N.A. \\
\hline Employment, end of 2001 & 65 & 28 & 38 & 47 & 43 \\
\hline \multicolumn{6}{|c|}{ Operating Expenses (SEK millions) } \\
\hline Personnel costs & 74 & 22 & 51 & 55 & 64 \\
\hline External asset & 78 & 47 & 5 & 18 & 124 \\
\hline \multicolumn{6}{|l|}{ management } \\
\hline Other administrative costs & 24 & 118 & 54 & 102 & 84 \\
\hline Total Operating expenses & 176 & 187 & 110 & 175 & 272 \\
\hline
\end{tabular}

Notes:

$\mathrm{NA}=$ Not available

Data for 1st AP fund are from pp. 6, 46 of 2001 Annual Report (English version)

Data for Second AP fund are from pp. 1, 18 of 2001 Annual Report (English version)

Data for Third AP fund are from pp. 10, 11, 15,20 of 2001 Annual Report (English version)

data for 4th AP fund are from pages, 19, 20, 33 of 2001 Annual Report (English version)

Data for 6th AP fund are from pages, 2,24,25 of 2001 Annual Report (English version) 


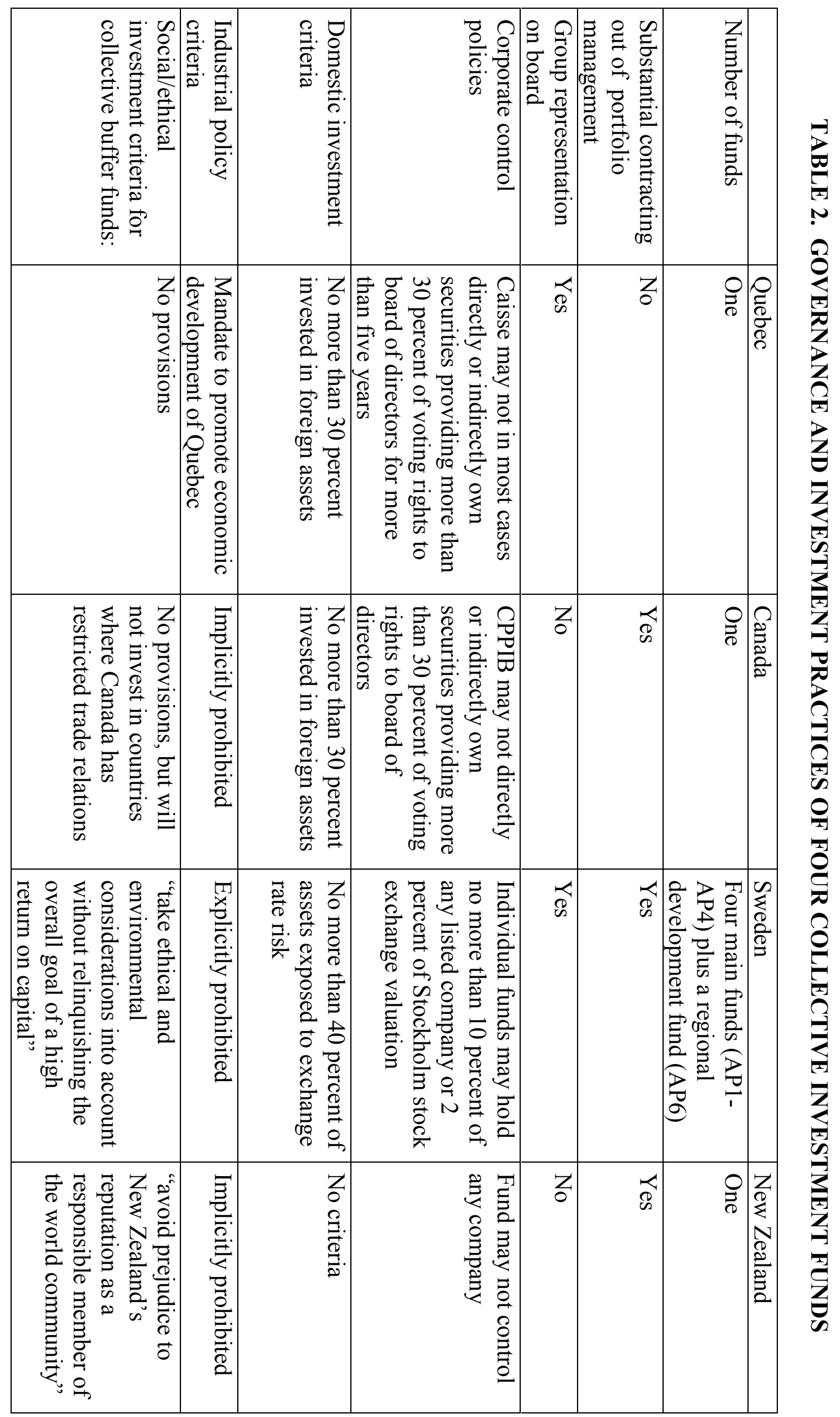




\section{RECENT WORKING PAPERS FROM THE \\ CENTER FOR RETIREMENT RESEARCH AT Boston COLLEGE}

The Role of Marital History, Early Retirement Benefits, and the Economic Status of Women

Tay K. NcNamara, Regina O'Grady-Leshane, and John B. Williamson, January 2003

Job Search Behavior at the End of the Life Cycle

Hugo Benitez-Silva, December 2002

Forecasting Incidence of Work Limitations, Disability Insurance Receipt, And Mortality in Dynamic Simulation Models Using Social Security Administrative Records: A Research Note

Melissa Favreault, December 2002

Medicare, Retirement Costs, and Labor Supply at Older Ages

Richard W. Johnson, December 2002

The Rise in Disability Recipiency and the Decline in Unemployment

David H. Autor and Mark G. Duggan, September 2002

Disability and Employment: Reevaluating the Evidence in Light of Reporting Errors

Brent Krieder and John V. Pepper, September 2002

The Effect of Unplanned Changes in Marital and Disability Status: Interrupted Trajectories and Labor Force Participation

John B. Williamson and Tay K. McNamara, September 2002

Health Insurance and the Disability Insurance Application Decision Jonathan Gruber and Jeffrey Kubik, September 2002

Projecting Poverty Rates in 2020 for the 62 and Older Population: What Changes Can We Expect and Why?

Barbara A. Butrica, Karen Smith, and Eric Toder, September 2002

Social Security and the Private Pension System: The Significance of Integrated Plans

Pamela Perun, July 2002

Pension Reform in the Presence of Financial Market Risk

Barry Bosworth and Gary Burtless, July 2002

All working papers are available on the Center for Retirement Research website (http://www.bc.edu/crr) and can be requested by e-mail (crr@bc.edu) or phone (617-552-1762). 